\title{
The physiological bases of nutrient responses during lactation
}

\author{
By P. W. MoE and H. F. Tyrrell, United States Department of Agriculture, \\ Agricultural Research Service, Beltsville, Md 20705, USA
}

The lactating dairy cow responds to dietary changes according to the nutrients provided and her propensity to produce milk. The allocation of nutrient use to milk production or body gain is generally termed 'partition' and has been shown to be a function of both the animal and its diet. As feed intake is increased, the lactating cow responds with progressively smaller increments of increased milk yield and progressively larger increments of body tissue. This 'diminishing return' is not associated with a change in efficiency of any physiological process. It is the result of changes in the rates of synthesis of milk components and of body tissue. The individual rates of milk synthesis and body tissue synthesis may be influenced independently. It is therefore somewhat awkward to speak of control of partition as though it were a single physiological process. We are concerned with the synthesis of specific milk constituents and the role of specific metabolites in influencing the rates of synthesis and, thereby, milk yield and composition.

It is unfortunately very difficult to tell if milk production is limited by nutritional state, i.e. nutrient supply, or by the hormone balance or other physiological factors involved in milk synthesis. There is very clearly a close interaction between nutrient supply and physiological control of milk synthesis. Bauman \& Currie (1980) used the term 'homeorhesis' which they credit to Kennedy (I967) to refer to the coordinated changes in metabolism of body tissues necessary to support a physiological state such as lactation. It is clear that nutrient response is altered by physiological state and that for a given physiological state, milk production will be influenced by nutrient supply.

Recent reviews have extensively discussed the endocrine control of partition and milk biosynthesis (Hart, 1983; Akers, 1985), mammary-gland differentiation (Houdebine, 1985), uptake and utilization of amino acids by the mammary gland (Clark, 1975; Mepham, 1982), and glucose homeostasis (McDowell, 1983). It is apparent that the control of milk synthesis or partition involves both substrate availability and endocrine control. The effects of substrate availability may be presumed from experiments in which dietary manipulation has caused a change in rate of milk synthesis and a corresponding change in body-tissue energy balance.

\section{Diet manipulation}

Increased milk yield at equal metabolizable energy (ME) intake was obtained at higher proportions of forage in the diet of lactating cows in experiments reported by Flatt $e t$ al. $(1969 a, b)$. The results of that study are shown in Table $\mathrm{I}$. 
Table 1. Effect of proportion of dietary forage at equal metabolizable energy $(M E)$ intake on milk yield in cows (from Flatt et al. 1969a,b)

Hay-grain (w/w) ...
ME intake (MJ)
Energy balance (MJ)
Milk energy (MJ)
Tissue energy (MJ)
Milk fat (\%)
Acetate:propionate

$\begin{array}{ccc}60: 40 & 40: 60 & 20: 80 \\ 151 \cdot 1 & 152 \cdot 4 & 145 \cdot 9 \\ 50 \cdot 0 & 52 \cdot 8 & 50 \cdot 9 \\ 58 \cdot 4 & 55 \cdot 1 & 43 \cdot 6 \\ -8 \cdot 4 & -2 \cdot 3 & 7 \cdot 3 \\ 3 \cdot 5 & 3 \cdot 0 & 2 \cdot 7 \\ 3 \cdot 32 & 2 \cdot 57 & 2 \cdot 00\end{array}$

Cows given the $600 \mathrm{~g}$ forage/ $/ \mathrm{kg}$ diet produced more milk and lost more body-tissue energy than cows given $200 \mathrm{~g}$ forage $/ \mathrm{kg}$. The acetate:propionate value was also higher on the $600 \mathrm{~g}$ forage/ $\mathrm{kg}$ diet. Tyrrell et al. (1973) found that an increment of added beet pulp yielded a greater proportion of increased energy balance as milk than an equal increment of maize grain. No information was available on rumen volatile fatty acids (VFA).

Journet et al. (1976) found that when energy intake varied around the level of requirement, about one-third of the increment of energy went into milk and two-thirds into body gain.

\section{Effects of specific nutrients}

The effect of individual VFA on partition was demonstrated by Armstrong \& Blaxter (1965). Infusion of acetate into the rumen of lactating goats resulted in increased milk synthesis and decreased body fat deposition, whereas with propionate infusion the reverse was true. Ørskov et al. (1969) obtained similar results with lactating cows. Acetic acid infusion resulted in more milk energy and less gain of body energy than did propionic acid infusion. Whether animal responses to propionate are directly translatable to glucose is not certain. A higher proportion of propionate may not indicate any difference in glucose availability. Herbein et al. (1978) found no difference in glucose pool size or irreversible loss between animals consuming 800 or $300 \mathrm{~g}$ grain $/ \mathrm{kg}$ diets despite differences in propionate availability.

Clark (1975) reviewed extensive studies of the relation between amino acid nutrition and milk yield. He emphasized the interrelation between glucose and amino acid nutrition in lactation and the importance of gluconeogenesis to the glucose supply for milk synthesis. He also cautioned against the assumption that improved glucose or starch availability to the small intestine ensured increased glucose absorption or that increased glucose absorption increased total glucose availability to the mammary gland. He concluded that the improved milk yield of $\mathrm{I}-4 \mathrm{~kg} / \mathrm{d}$ from post-rumen supplementation of casein could be due to glucose, amino acids, hormone secretion or a combination of these factors.

Tyrrell et al. (1982b) emphasized the role of protein in the energy economy of the lactating cow. Neither level of protein nor solubility of protein affected efficiency of ME use by lactating cows, but did affect the amount of ME available 
from the diets. Higher protein levels or less-soluble protein sources appeared to provide a more effective means of absorbing energy-yielding nutrients than the starchy material they replaced. Vermorel et al. (1982) also found an effect of protein on ME value of the diet but no effect on efficiency of energy use. It is clear that dietary protein plays a key role in absorption and metabolism in lactation beyond that associated with the supply of required amino acids.

Information of a quantitative nature about nutrients actually absorbed from the gastrointestinal tract is now becoming available. Huntington (1982, 1984) measured the net uptake of nutrients by the portal system in non-lactating and in lactating cows. He found large negative values for net glucose absorption in non-lactating cows at restricted feed intakes. Although lactating animals consumed more than twice as much dry matter, and portal blood flow was more than doubled, net glucose uptake was $-9 \mathrm{~g} / \mathrm{d}$. These values are shown in Table 2.

Results of this type support the caution expressed by Clark (1975) regarding the availability of nutrients to the small intestine as an indicator of nutrients available to the mammary gland.

Davis \& Collier ( 1985 ) cite a number of reviews of mammary nutrient supply and partitioning, blood flow and substrate requirements and caution that the response to nutrient supplementation depends on the control diet. In studies of mammary blood flow and nutrient concentrations, they concluded that of the three factors influencing intracellular availability of substrates for milk synthesis-blood concentration, blood flow, and membrane transport-the latter two are the most important, although blood concentrations of some substrates (acetate and tryptophan) may become critically limiting during brief fasting. They also concluded that the steep gradient of concentration of substrates across the mammary epithelial cell membrane suggests that a major impediment to substrate supply for milk synthesis is the rate of substrate transport across the membrane.

Forsberg et al. (1984), studying tissue slices from the mammary glands of six lactating Holstein cows, found that glucose had a large 'permissive' effect on acetate conversion to fatty acids. Acetate metabolism was independent of the availability of lactate.

Table 2. Net absorption of glucose by the portal system of lactating and non-lactating cows (from Huntington, 1982, 1984)

(Mean values with their standard errors for four observations per group)

\begin{tabular}{|c|c|c|c|c|}
\hline & \multicolumn{2}{|c|}{ Non-lactating } & \multicolumn{2}{|c|}{ Lactating } \\
\hline & Mean & SE & Mean & SE \\
\hline $\begin{array}{l}\text { Live wt }(\mathrm{kg}) \\
\text { Dry matter intake }(\mathrm{kg} / \mathrm{d}) \\
\text { Portal blood flow }(1 / \mathrm{h}) \\
\text { Net absorption of glucose }(\mathrm{g} / \mathrm{d}) \\
\text { Milk yield }(\mathrm{kg} / \mathrm{d})\end{array}$ & $\begin{array}{c}493 \\
5 \cdot 02 \\
632 \\
-164 \\
0\end{array}$ & $\begin{array}{c}23 \\
0.23 \\
24 \\
24\end{array}$ & $\begin{array}{c}5 \times 3 \\
13.5 \\
1328 \\
-9 \\
23.7\end{array}$ & $\begin{array}{c}27 \\
0.53 \\
119 \\
42 \\
2 \cdot 2\end{array}$ \\
\hline
\end{tabular}




\section{Effects of endocrine system}

Hart ( 1983 ) reviewed the interrelations between the endocrine system, especially growth hormone and prolactin, and dietary manipulation in lactating cows. He summarized findings in which fat content of milk and fat yield were reduced for cows fed twice rather than six times daily (Sutton et al. 1982). Feeding six times daily did not influence prolactin, growth hormone or thyroxine, but decreased the average level of insulin by about half through virtual elimination of post-prandial insulin peaks. He suggested that the increase in insulin following meal feeding is more important to partition than the average concentration through the day.

Dramatic increases in milk yield have been achieved with the administration of growth hormone (Bauman et al. 1982 ). Cows averaging $32 \mathrm{~kg}$ milk/d were given, by subcutaneous injection, $25 \mathrm{mg} / \mathrm{d}$ of either natural or recombinantly-derived growth hormone for $6 \mathrm{~d}$. Milk yields increased by 10.3 and $12.9 \%$ over those of controls. Increases have been even greater in other experiments. Eppard et al. (1985) treated six Holstein cows with $0,5,25,50$ and roo IU pituitary-derived growth hormone/d. During the last $5 \mathrm{~d}$ of a ro $\mathrm{d}$ injection period milk yield, protein and fat increased with dose rate up to 32,27 and $46 \%$ above those of controls at the roo IU level.

Administration of 52 IU growth hormone in a single reversal experiment by Tyrrell et al. (1982a) resulted in milk energy increasing from $24 \cdot 1$ to $31 \cdot 7 \%$ of energy intake while body-tissue energy decreased from $-1 \cdot 4$ to $-13.8 \%$ of energy intake. Information on heat production suggested no effect of growth hormone on efficiency of milk synthesis. Bitman et al. (1984) studied the changes in milk fat composition in these studies. Fat from growth hormone treatment had $6 \%$ more long-chain $\mathrm{C}_{18: 1}$ fatty acids. Overall changes of blood and mills lipids are consistent with the concept that adipose tissue reserves were mobilized in response to hormone treatment and that these mobilized lipids were the major carbon source for the $41 \%$ increase of milk fat secretion. These observations are consistent with the hypothesis that a substantial portion of milk fat, long-chain fatty acids in particular, is synthesized in adipose tissue and transported to the mammary gland in the normal course of events involved in milk synthesis.

\section{Conclusions}

The lactating cow responds to dietary changes according to the effect of these changes on the nutrient supply to the secretory cells in relation to the physiological 'ability' to produce milk. Nutrient supply is definable at several levels: feed consumption, end-products of digestion, net portal absorption, mammary gland uptake, and intracellular and subcellular concentrations. Nutrient supply to secretory cells in the mammary gland directly influences milk synthesis as it relates to substrates required for milk synthesis. The nutrient supply at the level of net portal absorption interacts with the endocrine system in the homeorhetic role of the latter in coordinating optimum milk synthesis. Changes in the supply of 
nutrient absorbed from the gastrointestinal tract trigger endocrine events that in turn influence metabolite supply to the mammary gland. Improvements in understanding the specific modes of action of individual hormones such as growth hormone and the control of their release or that of their precursors will permit more precise prediction and control of the uptake or transport of a variety of nutrients. An important aspect of understanding the endocrine system for nutritionists is to identify the specific nutrient or nutrients which are keys to evoking responses in the endocrine system which result in shifts in composition of milk produced and shifts in balance of body tissue energy, whether that shift is a consequence of altered nutrient supply available to the mammary gland or is due to a direct effect of hormone action on the biochemical process of synthesis of specific milk components in the mammary gland.

\section{REFERENCES}

Akers, R. M. (1985). Journal of Dairy Science 68, 50 r-519.

Armstrong, D. G. \& Blaxter, K. L. (1965). Proceedings 3rd Symposium on Energy Metabolism, European Association for Animal Production. Publication no. i I, 59-70.

Bauman, D. E. \& Currie, W. B. (1980). Journal of Dairy Science 63, $15^{14-1} 529$.

Bauman, D. E., DeGeeter, M. J., Peel, C. J., Lanza, G. M., Gorewit, R. C. \& Hammond, R. W. (1982). Fournal of Dairy Science 65, suppl. I, 121.

Bitman, J., Wood, D. L., Tyrrell, H. F., Bauman, D. E., Peel, C. J., Brown, A. C. G. \& Reynolds, P. J. (1984). Fournal of Dairy Science 67, 2873-2880.

Clark, J. H. (1975). Foumal of Dairy Science 58, I $178-1197$.

Davis, S. R. \& Collier, R. J. ( 1985 ). Fournal of Dairy Science 68, $104 \mathrm{I}-1058$.

Eppard, P. J., Bauman, D. E. \& McCutcheon, S. N. (1985). Fournal of Dairy Science 68, I109-1115.

Flatt, W. P., Moe, P. W., Moore, L. A., Hooven, N. W., Lehman, R. P., Ørskov, E. R. \& Hemken, R. W. (1969a). Proceedings 4th Symposium on Energy Metabolism, European Association for Animal Production. Publication no. 1 2, $221-234$.

Flatt, W. P., Moe, P. W., Munson, A. W. \& Cooper, T. (1969b). Proceedings 4 th Symposium on Energy Metabolism, European Association for Animal Production. Publication no. I2, 235-249.

Forsberg, N. E., Baldwin, R. L. \& Smith, N. E. (1984). Fournal of Dairy Science 67, 2247-2254.

Hart, I. C. (1983). Proceedings of the Nutrition Society 42, $181-193$.

Herbein, J. H., Van Maanen, R. W., McGilliard, A. D. \& Young, J. W. (1978). Fournal of Nutrition 108, 994-100r.

Houdebine, L. (1985). Fournal of Dairy Science 68, 489-500.

Huntington, G. B. (1982). Fournal of Dairy Science 65, 1 1 $55^{-1} 162$.

Huntington, G. B. (1984). Fournal of Dairy Science 67, $1919-1927$.

Journet, M., Verite, R. \& Remond, B. (1976). Proceedings 7 th Symposium on Energy Metabolism, European Association for Animal Production. Publication no. $19,323-326$.

Kennedy, G. C. (1967). Handbook of Physiology, sect. 6, vol. 1, p. 337 [C. F. Code, editor]. Washington DC: American Physiological Society.

McDowell, G. H. (1983). Proceedings of the Nutrition Society 42, 149-167.

Mepham, T. B. (1982). Journal of Dairy Science 62, 287-298.

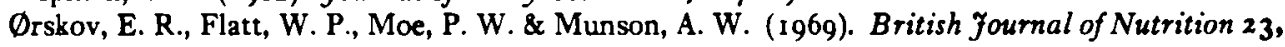
443-453.

Sutton, J. D., Hart, I. C. \& Broster, W. H. (1982). Proceedings of 9th Symposium on Energy Metabolism, European Association for Animal Production. Publication no. 29, 26-29.

Tyrrell, H. F., Brown, A. C. G., Reynolds, P. J., Haaland, G. L., Peel, C. J., Bauman, D. E. \& Steinhour, W. D. (1982a). fournal of Dairy Science 65, suppl. 1, 120. 
Tyrrell, H. F., Haaland, G. L., Moe, P. W. \& Brown, A. C. G. (1982b). Proceedings of gth Symposium on Energy Metabolism, European Association for Animal Production. Publication no. 29, 14-17.

Tyrrell, H. F., Moe, P. W. \& Bull, I. S. (1973). Fournal of Dairy Science 56, 1384 Abstr.

Vermorel, M., Remond, B., Vernet, J. \& Liamadis, D. (1982). Proceedings of gth Symposium on Energy Metabolism, European Association for Animal Production. Publication no. 29, i 8-21. 